\title{
PROSEDUR PENETAPAN BANTUAN STIMULAN PERUMAHAN SWADAYA PERSPEKTIF FIQIH SIYASAH DUSTURIYAH \\ (Studi Kasus Di Jorong Buluh-Kasok Kenagarian Padang Air Dingin Kecamatan Sangir Jujuan Kabupaten Solok-Selatan)
}

\author{
${ }^{1}$ Srima Yengsi ${ }^{1}$, Sulastri Caniago² \\ ${ }^{1}$ Institut Agama Islam Negeri Batusangkar \\ e-mail: srimayengsi89@gmail.com \\ 2Institut Agama Islam Negeri Batusangkar \\ e-mail: sulastricaniago@iainbatusangkar.ac.id
}

\begin{abstract}
This paper aims to explain the procedure for determining self-help housing stimulant assistance in Jorong Bulub-Kasok Nagari Padang Air Cold, Sangir Jujuan District, Solok-Selatan Regency based on the Minister of PUPR Regulation Number 13/PRT/M/2016 and the Fiqh Siyasah Duturiyah Perspective. The type of research is field research (field research). The data sources of this study consisted of primary data sources, namely the head of the technical team for house renovation in Solok-Selatan Regency, the head of the administrative section of the wali nagari, the head of jorong Bulub-Kasok, community leaders in Jorong Bulub Kasok and secondary data, namely scientific books, research results, legislation related to research and documents. Data collection techniques are interviews and documentation. The data were analyzed using a qualitative descriptive method. This study found that the cause of the mechanism for determining the self-help housing stimulant assistance in Jorong Bulub Kasok was not right on target because there were parties who did not carry out their technically determined duties. Of the three persons in charge and requesting house renovation assistance, namely: the Technical Team for house renovation, the Wali Nagari Padang Air Cold, and Jorong Buluh-Kasok. The party who does not carry out their duties is the technical team for home renovation, where the technical team does not carry out their duties as supervisors for the implementation of home renovation assistance, while in Ministerial Regulation No. and evaluation of the provision of home surgery assistance. Meanwhile, according to Fiqh Siyasah Duturiyah's view of the procedure for determining this self-help housing stimulant assistance, it lies in the task of the executive agency (al-sultah al-tanfidriyah) where the task of the al-sultah al-tanfidriyah institution is to implement the laws and regulations that have been set., in the principle of figh siyasa this is included in the principle of justice where to create justice one must not look at status or position.
\end{abstract}

Keywords: Bantuan Stimulan Perumahan Swadaya, Siyasah Dusturiyah

\section{PENDAHULUAN}

Indonesia merupakan negara hukum sebagaimana sudah tercantum dalam pasal 1 ayat (3) undang-undang dasar 1945 yang berbunyi negara Indonesia adalah negara hukum. Negara hukum menurut Bothling, adalah "de staat, waarin de wilsvrijheid van gezagsdrager is beperkt door grenzen van rech" (negara, dimana kebebasan kehendak pemegang kekuasaan di batasi oleh ketentuan hukum) Alga dan Jansen, mengemukakan bahwa negara hukum menjadikan hukum sebagai aturan main dalam penyelenggaraan kenegaraan, pemerintahan dan kemasyarakatan. (Ridwan, 2006:18-20)

Sebagai negara hukum Indonesia dalam memenuhi tujuan dan cita-cita negara yang tercantum dalam Pancasila dan Undang-Undang Dasar 1945 Negara Republik Indonesia 
menjalankan roda pemerintahan berlandaskan kepada Hirarki Perundang-undangan sebagaimana yang di cantumkan di dalam pasal 7 ayat (1) Undang-Undang Nomor 12 tahun 2011 tentang pembentukan peraturan perundang-undangan yaitu : (1) Undang-Undang Negara Republik Indonesia Tahun 1945; (2) Ketetapan majelis Permusyawaratan rakyat;(3) Undang-Undang/Peraturan Pemerintah pengganti Undang-Undang;(4)Peraturan pemerintah; (5) Peraturan Presiden; (6)Peraturan Daerah Provinsi; (7) Peraturan Daerah Kabupaten Kota; (Undang-Undang Nomor 12 tahun 2011 tentang pembentukan peraturan perundang-undangan).

Peraturan menteri dalam Undang-Undang Nomor 12 Tahun 2011 tentang Pembentukan Peraturan Perundang-undangan tidak diatur dalam ketentuan Pasal ayat (1). Namun demikian, jenis peraturan tersebut keberadaannya diatur dalam Pasal 8 ayat (1) UU No. 12/2011, yang menegaskan: "Jenis Peraturan Perundang-undangan selain Permasalahan dalam skripsi ini adalah Bagaimana prosedur penetapan bantuan stimulan perumahan swadaya di Jorong Buluh-Kasok Nagari Padang Air Dingin Kecamatan Sangir Jujuan Kabupaten Solok-Selatan berdasarkan Peraturan Menteri PUPR Nomor 13/PRT/M/2016 dan Perspektif Fiqh Siyasah Dusturiyah sebagaimana dimaksud dalam Pasal 7 ayat (1) mencakup peraturan yang ditetapkan oleh Majelis Permusyawaratan Rakyat, Dewan Perwakilan Rakyat, Dewan Perwakilan Daerah, Mahkamah Agung, Mahkamah Konstitusi, Badan Pemeriksa Keuangan, Komisi Yudisial, Bank Indonesia, Menteri, badan, lembaga, atau komisi yang setingkat yang dibentuk dengan Undang-Undang atau Pemerintah atas perintah Undang-Undang, Dewan Perwakilan Rakyat Daerah Provinsi, Gubernur, Dewan Perwakilan Rakyat Daerah Kabupaten/Kota, Bupati/Walikota, Kepala Desa atau yang setingkat."

Meskipun ketentuan di atas tidak menyebut secara tegas jenis peraturan perundangundangan berupa "Peraturan Menteri", namun frase peraturan yang ditetapkan oleh menteri mencerminkan keberadaan Peraturan Menteri sebagai salah satu jenis peraturan perundangundangan. Dengan demikian, Peraturan Menteri setelah berlakunya UU No. 12/2011 tetap diakui keberadaannya.

Salah satu peraturan Menteri adalah Peraturan Menteri PUPR No 13/PRT/M/2016 tentang Bantuan Stimulan Perumahan Swadaya. Dalam peraturan Menteri PUPR No 13/PRT/M/2016 tentang bantuan stimulan perumahan swadaya menjelaskan secara umum tentang Prosedur penyelenggaraan bantuan stimulan perumahan swadaya, yaitunya :

1. Penetapan lokasi BSPS

2. Penetapan calon penerima BSPS

3. Penyaluran BSPS

4. Pembinaan pelaksanaan

5. Pemantauan dan Evaluasi

Pelaksanan dan penanggung jawab bantuan stimulan perumahan swadaya di tingkat daerah di lakukan Tim Teknisi Kabupaten/Kota yang terdiri atas unsur :

a. SKPD (Satuan Kerja Perangkat Daerah) yang menangani bidang perumahan, sebagai ketua di pegang oleh kepala Teknis bedah rumah Dinas perumahan dan permukiman Kabupaten / kota.

b. SKPD (satuan Kerja Perangkat Daerah) yang menangani bidang perencanaan pembangunan sebagai sekretaris jabatan ini di pegang oleh sekretaris Dinas perumahan dan permukiman Kabupaten/kota. 
c. SKPD (satuan kerja perangkat daerah) yang menangani bidang pemberdayaan sebagai anggota.

d. Camat di lokasi BSPS (Bantuan Stimulasi Perumahan Swadaya) sebagai anggota.

e. Kepala Desa/Lurah di lokasi BSPS (Bantuan Stimulasi. Perumahan Swadaya) sebagai anggota

Berikut tugas-tugas dan tanggung jawab Tim teknisi Kabupaten/Kota yang sudah di tunjuk:

1) Melakukan sosialisasi dan penyuluhan kepada masyarakat Melakukan seleksi calon penerima BSPS (Bantuan Stimulasi Perumahan Swadaya)

2) Memverifikasi proposal dari calon penerima BSPS (Bantuan Stimulasi Perumahan Swadaya)

3) Melakukan pembinaan dan pendampingan masyarakat (4)Melakukan pengawasan dan pengendalian (5)Melakukan pemantauan dan evaluasi

Dalam konteks bernegara Islam permasalahan ini termasuk kedalam kajian Siyasah Dusturiyah. Siyasah dusturiyah adalah bagian Fiqh siyasah yang membahas masalah perundang-undangan negara. Dalam hal ini juga dibahas konsep-konsep konstitusi (undangundang dasar negara dan sejarah lahirnya perundang-undangan dalam suatu negara), legislasi (bagaimana cara perumusan undang-undang), lembaga demokrasi dan syura yang merupakan pilar penting dalam perundang-undangan tersebut. Disamping itu, kajian ini juga membahas konsep negara hukum dalam siyasah dan hubungan timbal balik antara pemerintah dan warga negara serta hak-hak warga negara yang wajib dilindungi. (Muhammad Ikbal, 2016: 177)

Dalam ruang lingkup siyasah dusturiyah persoalan ini termasuk kedalam konteks Siyasah Tanfidziyah yaitu persoalan pelaksana undang-undang atau penerapan peraturan di dalam masyarakat, Islam mengajarkan kita untuk mematuhi undang-undang dan peraturan yang di buat oleh para pemimpin apabila peraturan tersebut tidak bertentangan dengan syariat Islam yaitu Al-Quran dan Sunnah.

\section{METODE PENELITIAN}

Jenis penelitian yang digunakan adalah jenis penelitian lapangan. Sumber data penelitian ini terdiri dari sumber data primer yaitu kepala tim teknis bedah rumah Kabupaten SolokSelatan, kepala seksi bagian administrasi wali nagari, kepala jorong Buluh-Kasok, tokoh Masyarakat Jorong Buluh Kasok dan data sekunder yaitu buku-buku ilmiah, hasil peneitin, perundang- undangan yang terkait dengan penelitian dan dokumen. Teknik pengumpulan data adalah wawancara dan dokumentasi. Setelah data tersebut diperoleh, selanjutnya data dianalisis menggunakan metode deskriptif kualitatif. Untuk menjamin keabsahan data digunakan uji kredibilitas data yang dilakukan melalui triangulasi.

\section{HASIL DAN PEMBAHASAN}

Bantuan Stimulan Perumahan Swadaya yang selanjutnya disingkat BSPS adalah bantuan pemerintah berupa stimulan bagi masyarakat berpenghasilan rendah untuk meningkatkan keswadayaan dalam pembangunan/ peningkatan kualitas rumah beserta prasarana, sarana, dan utilitas umum. Masyarakat Berpenghasilan Rendah yang selanjutnya disingkat MBR 
adalah masyarakat yang mempunyai keterbatasan daya beli sehingga perlu mendapat dukungan pemerintah untuk memperoleh rumah yang layak huni.

\section{Prosedur Kegiatan BSPS}

1. Koordinasi dengan para pemangku kepentigan

Koordinasi dengan pemangku kepentingan disini merupakan koordinasi dari Tim Teknis bedah rumah Kabupaten dengan Camat, Wali Nagari, Jorong, Bamus dan PMN tempat pelaksanaan BSPS.Sesuai dengan hasil wawancara penulis dengan kepala teknis bedah rumah kabupaten beliau menjelaskan bahwa Sebelum pelaksanaan BSPS tim teknis bedah rumah kabupaten akan melakukan koordinasi terlebih dahulu dengan camat, wali nagari, jorong, bamus dan PMN tempat pelaksanaan BSPS terebut.

2. Sosialisasi calon penerima bantuan (CPS)

Sosialisasi tentang apa itu bedah rumah secara umum kepada calon penerima bantuan bedah rumah yang di lakukan oleh jorong dan wali nagari. Sebelum penetapan BSPS wali nagarai dan jorong akan memberikan sosialisasi dengan masyarakat tentang bantuan bedah rumah secara umum.

3. Vertifikasi dan identifikasi rencana penangan RLTH/Kekuranga

Merupakan pengecekan langsung ke lapangan mana rumah yang tidak layak huni dan memenuhi standar penerima bantuan bedah rumah, dalam hal ini yang turun ke lapangan mengecek rumah-rumah yang layak mendapatkan BSPS merupakan TFL dari kebupaten yang didampingi oleh TFL pendamping pihak wali nagari, dan kepala jorong, dalam hal ini tim teknis tidak turun ke lapangan di karenakan tim teknis hanya bertugas mengawasi jalannya BSP apakah sesuai dengan pedoman pelaksanaan atau tidak.

\section{Perorganisasian $\mathrm{CPB}$}

Setelah nama penerima bantuan bedah ruma di tetapkan oleh pihak pusat maka di buatkan kelompok-kelompok penerima oleh FLS pendamping. Dalam hal ini guna untuk memudahkan pemberian bantuan bedah dumah karena BSPS diberikan dalam bentuk dalam bentuk bahan bangunan maka di buatlah kelompok-kelompok oleh pihak jorong dan wali nagari

\section{Penyusuna Proposal}

Penyusunan proposal dilakukan oleh Fasilitator pendamping. dikarenakan yang menerima BSPS merupakan orang awam maka penyusunanproposal di lakukan oleh TFL Pendamping dimana mereka menanyakan kepada masyarakat tentang apa saja yang di butuhkan dalam pembangunan rumah masyarakat, suntuk melengkapi persyaratan di dalam proposal mengenai pembuatan surat keterangan kurang mampu dan surat keterangan akan di bantu oleh orang dari wali nagarai.

6. Pengesahan Proposal oleh Tim Teknis

Proposal yang sudah di buat oleh FLT pendamping di sahkan oleh Tim teknis bedah rumah melalui musyawarah, proposal yang di buat oleh TFL pendamping di serahkan kepada wali nagari guna untuk melengkapi persyaratan yang harus di penuhi seperti surat keterangan tidak mampu dan surat keterangan penghasilan maka setelah itu pihak wali yang akan memberikan proposal yang sudah lengkap tersebut kepada Tim Teknis kabupaten guna untuk di musyawarahkan siapa yang akan di tetapkan sebagai penerima BSPS Tersebut dan di sahkan proposal yang memenuhi persyaratan sebagai penerima BSPS

7. Pengusulan proposal ke PPK 
Proposal yang di sahkan di berikan kepada pejabat pembuat komitmen yang diberikan kewenangan oleh pengguna anggaran untuk mengambil keputusan. Setelah proposal di sahkan oleh Tim teknis maka proposal di serahkan kembali kepada PPK yang di sertai dengan buku tabungan masing-masing peneria BSPS dan PPK lah yang akan mengambil keputusan mengenai penggunaan anggaran BSPS tersebut.

8. Penetapan penerima BSPS

Setelah semua prosedur di laksanakan maka selanjutnya merupakan penetapan penerima BSPS dengan penyerahan langsung bantuan berupa bahan bangunan kepada BSPS.

Berdasarkan penjelasan dari bapak Iwan selaku Kepala Tim Teknis bedah rumah Kabupaten Solok-Selatan mengatakan bahwa prosedur yang harus di lalui oleh penerima bantuan stimulan perumahan swadaya salah satunya adalah memenuhi kriteria sebagai penerima bantuan stimulan perumahan swadaya sebagaimana yang tertera dalam Pasal 13 peraturan Menteri PUPR No 13/PRT/M/2016 tentang bantuan stimulan perumahan swadaya untuk mengetahunyai Tenaga Fasilitator yang turun langsung ke lapangan karena tim teknis hanya bertugas melaksanakan pengawan terhadap pelaksanaan bantuan bedah rumah di dampingi oleh kepala jorong dan wali nagari dan pendamping desa, turun langsung ke lapangan untuk melihat langsung kelapangan siapa saja yang akan menjadi calon penerima bantuan bedah rumah tersebut dan tim teknis akan meminta data-data yang di perlukan, di lapangan selain mengecek keadaan rumah dari calon penerima bantuan bedah rumah tim teknis akan meminta fotocopy KK,KTP dan surat tanah dari calon penerima bantuan bedah rumah. KK dan KTP gunakan untuk melihat berapa banyak anggota keluarga yang tinggal di dalam rumah tersebut dan untuk melihat sudah berapa lama calon penerima bantuan bedah rumah berkeluarga hal ini di karenakan salah satu syarat untuk mendapatkan bantuan bedah rumah adalah berkeluarga minimal 5 Tahn hal ini di karenakan untuk menghindari kecemburuan sosial di tengah masyarakat. Surat tanah, surat tanah ini pihak tim teknis tidak memberi keharuskan dalam berbentuk sertifikat namun juga bisa dalam bentuk surat hibah bantuan bedah rumah.

Setelah masyarakat memenuhi persyaratan sebagai penerima bantuan bedah rumah maka data nama-nama masyarakat calon penerima bantuan bedah rumah akan di berikan kepada wali nagari guna untuk melengkapi administrasi calon penerima bantuan bedah rumah seperti proposal, foto rumah dan hal-hal lain yang di perlukan, setelah itu wali nagari baru mengajukan data-data nama calon penerima bantuan bedah rumah, jika proposal sudah sampai kepada Dinas maka pihak dinas akan bermusyawarah guna untuk menyeleksi kembali mana yang memang benar-benar layak untuk menerima bantuan bedah rumah. Setelah itu proposal dari masyarakat yang menerima bantuan bedah rumah di kembalikan kepada wali nagari dalam berbentuk data nama-nama dan di sertai dengan buku rekening penerima bantuan bedah guna untuk pencairan dana, setelah itu tim Fasilitator akan mengambil uang dari rekening sipenerima guna untuk membelikan bahanbangunan di toko bangunan terdekat tempat pelaksanaan BSPS hal ini guna tidak ada penyelewengan dina yang dilakukan oleh penerima bantuan bedah sumah. memberikan bantuan Pelaksanaan bantuan bedah rumah di laksanakan selama 4 bulan, jika masyarakat tidak menyelesaikan pembangunan selama 4 bulan tersebut maka masyarakat harus mengembalikan bahan bangunan yang telah diberikan.

Berdasarkan penjelasan dari Ibuk Silvia Gusta Pratama selaku kepala seksi administrasi kantor wali Nagari Padang Air Dingin mengatakan bahwa dalam prosedur pemberian bantuan 
stimulan perumahan swadaya pihak dari kewalian tidak ikut campur dan tidak tahu menau kecuali pengusulan nama-nama dari masyarakat yang akan menerima bantuan stimulan perumahan swadaya yang diajukan oleh kepala jorong, dan pembutan surat pernyaan tidak mampu dan surat keterangan penghasilan dan yang turun ke lapangan adalah Tenaga fasilitator di dampingi oleh piah wali nagari, jorong dan pendamping desa. hal ini di karenakan pihak wali nagari tidak memiliki tugas dalam pelaksanan bantuan bedah rumah (Ibuk Silvia Gusta Pratama, wawancara, Padang Air Dingin, 09 Juni 2020 jam 09:00)

Berdasarkan penjelasan dari Bapak Rio Puspa Irawan, S.H selaku kepala jorong Nagari Buluh-Kasok tahun 2018, beliau mengatakan bahwa Tim Fasilitator kabupaten di dampingi oleh pihak wali nagari yang di wakili Kepala seksi bidang HUMAS, jorong dan pendaping desa langsung ke lapangan bertanya dan mengamati siapa yang layak untuk menerim bantuan bedah rumah sesuai dengan persyaratan sebagai penerima bantuan bedah rumah yang sudah tertera dalam Pasal 13 Peraturan Mentri PUPR No 13/PRT/M/2016 tentang Bantuan Stimulan Perumahan Swadaya syarat yang harus dipenuhi yang lainnya adalah memiliki KK (Kartu Keluarga), KTP (Kartu Tanda Penduduk), tanah yang dibuktikan dengan surat kepemilikan tanah baik itu sertifikat maupun surat Hibah dan memiliki keturunan sebagai generasi penerus. Proses pelaksanaan bantuan bedah rumah yang pertama adalah tim teknis bedah rumah mengecek langsung kelapangan calon-calon penierima bantuan bedah rumah dan meminta syarat- syarat yang harus di penuhi, kemudian nama-nama masyarakat yang memenuhi persyaratan akan di berikan kepada walai nagari guna untuk menyiapkan administrasi yang di perlukan calon penerima bantuan bedah rumah seperti surat keterangan tidak mampu, surat keterangan penghasilan. setelah itu wali nagari baru mengajukan data-data nama calon penerima bantuan bedah rumah dalam bentuk proposal dari masing-msing calon kepada dinas.

Setelah itu proposal dari masyarakat yang menerima bantuan bedah rumah akan di kembalikan oleh dinas kepada PPK dan di sertai buku tabungan guna pencairan dana bantuan bedah rumah, setelah itu tim Fasilitator akan mengambil uang dari rekening si penerima guna untuk membelikan bahanbangunan di toko bangunan terdekat tempat pelaksanaan BSPS hal ini guna tidak ada penyelewengan dina yang dilakukan oleh penerima bantuan bedah sumah. memberikan bantuan Pelaksanaan bantuan bedah rumah di laksanakan selama 4 bulan, jika masyarakat tidak menyelesaikan pembangunan selama 4 bulan tersebut maka masyarakat harus mengembalikan bahan bangunan yang telah diberikan.

Pelaksanaan bantuan bedah rumah dilaksanakan selama 4 bulan, mengenai jumlah penerima bantuan bedah rumah tidak ada ketentuannya karena yang akan menentukan hal tersebut adalah pihak Dinas sendiri. Selanjutnya mengenai ketentuan khusus dari jorong, dari pihak jorong tidak ada ketentuan khusus mengenai siapa saja yang menerima bantuan bedah rumah tersebut dan pihak jorong yang akan mengajukan nama-nama orang yang memenuhi persyaratan sebagai penerima bantuan bedah rumah. (Bapak Rio Puspa Irawan, S.H, wawancara, Buluh-Kasok, 09 Juni 2020 jam 14:00 )

Berdasarkan penjelasan dari bapak sihot selaku masyarakat yang menerima bantuan bedah rumah mengatakan bahwa ada orang dari Kantor Wali nagari, jorong dan orang-orang dari pelaksana bantuan bedah rumah yang datang kerumahnya menanyakan berapa hal namun sebelumnya orang tersebut memberi penjelasan tentang bedah rumah setelah itu baru bertanya berapa jumlah keluarga dalam satu rumah, berapa lama menikah, punya keturunan 
atau tidak, setelah itu mereka meminta fotocopy KK,KTP,dan surat tanah. pemberian bantuan bedah rumah diberikan dalam bentuk bahan bangunan yang terdiri dari beberapa tahapan. (Bapak,sihot, wawancara, Buluh-Kasok, 10 Juni 2020 jam 15:00 )

Berdasarkan penjelasan dari bapak Iyas selaku penerima bantuan bedah rumah beliau mengatakan bahwa sebelum menerima bantuan bedah rumah ada orang yang datang ke rumahnya yang di dampingi oleh kepala jorong dan orang dari wali nagari, orang tersebut menjelaskan tentang bantuan bedah rumah setelah itu baru bertanya mengenai beberapa ha yaitu : berapa orang yang tinggal dalam satu rumah, apakah punya keturunan, apakah ada ada surat keterangan kepemilikan tanah,KK dan KTP, bantuan bedah rumah diberikan dalam bentuk bahan bangunan yang melalui beberapa tahapan (Bapak Iyas, wawancara, BuluhKasok, 10 Juni 2020 jam 16:00)

Berdasarkan penjelasan dari Bapak Nopa Melodi Sandra, S.Ag selaku masyarakat yang menerima bantuan bedah rumah di Jorong Buluh-Kasok mengatakan bahwa sebelum menerima bantuan bedah rumah ada ketentuan - ketentuan yang harus dipenuhi terlebih dahulu, di antaranya memiliki KK, KTP, Surat kepemilikan tanah, punya keturunan. Bantuan diberikan dalam bentuk bahan bangunan yang diberikan dalam beberapa tahap, lama waktu yang diberikan dalam membangun rumah selama 4 bulan. (Bapak Nopa Melodi Sandra, wawancara, Buluh-Kasok, 10 Juni 2020 jam 17:00)

Berdasarkan penjelasan dari ibuk jarius selaku masyarakat yang tidak menerima bantuan bedah rumah namun di pandang layak untuk menerima bantuan bedah rumah mengatakan bahwa dulu pernah ada orang pergi kerumahnya yang sertai dengan kepala jorong dan oraang dari wali nagari yang menanyakan tentang berapa orang isi di dalam rumah, ada atau tidak surat kepemilikan tanah dan juga di minta fotocopy KK KTP dan Surat tanah semua yang di minta tersebut sudah di berikan kepada orang tersebut namun beliau tidak juga mendapatkan bantuan bedah rumah samapai sekarang ini. (Ibuk jarius, wawancara, Buluh-Kasok, 11 Juni 2020 jam 13:00)

Berdasarkan penjelasan dari Ibuk Ranti selaku masyarakat yang tidak menerima bantuan bedah rumah di Jorong Buluh-Kasok mengatakan bahwa pihak Dinas dan pihak Jorong pernah pergi kerumahnya bertanya beberapa hal salah satunya adalah apakah memiliki tanah, beliau menjawab beliau memiliki tanah namun karena keterbatasan biaya sehingga beliau tidak bisa membangun rumah di tanah miliknya tersebut sehingga sampai sekarang masih menumpang di rumah kosong orang lain dan beliau mengatakan bahwa jorong pernah meminta fotocopy KK, KTP, surat kepemilikan tanah untuk mengusulkan namanya sebagai penerima bantuan bedah rumah. Namun, sampai saat sekarang ini beliau tidak menerima bantuan bedah rumah. (Ibuk Ranti, wawancara, Buluh-Kasok, 11 Juni 2020 jam 14:30).

Dari hasil analisa penulis, penulis menemukan penyebab tidak terlaksanana mekanisme penetapan bantuan bedah rumah di Jorong Buluh Kasok, Kenagarian Padang Air Dingin, Kecamatan Sangir jujuan, Kabupaten Solok Selatan sesuai dengan pedoman dalah adanya pihak yang tidak melaksanakan tugasnya secara keseluruhan. Dari ketiga penanggung jawab dan pelaksana bantuan bedah rumah yaitunya Tim teknis bedah rumah, Wali Nagari dan Jorong tempat penlaksanaan BSPS, yang tidak melakukan tugas secara keseluruhan merupakan Tim Teknis kabupaten dimana berdasarkan Peraturan Menteri No 13/PRT/M/2016 Tim teknis bantuan bedah rumah bertugas melakukan pengawasan dan pengendalian serta melakukan pemantauan dan evaluasi terhadap pemberian bantuan bedah rumah. 
Hal inilah yang menjadi penyebap mekanisme penetapan bantuan stimulan perumahan swadaya di jorong buluh kasok tidak tepat sasaran, dimana yang seharusnya menerima bantuan bedah rumah namun tidak mendapatkan bantuan bedah rumah dan begitu sebaliknya, di karenakan kurangnya pengawasan yang di lakukan oleh Tim Teknis terhadap BSPS di lapangan.

Dalam kajian Islam persoalan ini termasuk kedalam konteks kajian Fiqh Siyasah Dusturiyah. Fiqh Siyasah Dusturiyah merupakan bagian fiqh siyasah yang membahas masalah perundang-undangan negara. Dalam hal ini juga dibahas antara lain konsep-konsep konstitusi (undang-undang dasar negara dan sejarah lahirnya perundang-undangan dalam suatu negara), legislasi (bagaimana cara perumusan undang-undang), lembaga demokrasi dan syura yang merupakan pilar penting dalam perundang-undangan tersebut. Di samping itu, kajian ini juga membahas konsep negara hukum dalam siyasah dan hubungan timbal balik antara pemerintah dan warga negara serta hak-hak warga negara yang wajib dilindungi.

Pembahasan dalam siyasah dusturiyah adalah hubungan antara pemimpin di satu pihak dan rakyatnya di pihak lain, serta kelembagaan-kelembagaan yang ada di dalam masyarakatnya. Oleh karena itu, dalam siyasah dusturiyah biasanya di batasi hanya membahas pengaturan dan perundang-undangan yang dituntut oleh hal ihwal kenegaraan dari segi persesuaian dengan prinsip-prinsip agama dan merupakan realisasi kemaslahatan manusia serta memenuhi kebutuhannya.

Dalam ruang lingkup kajian siyasah dusturiyah hal ini termasuk kedalam Al-sulthah altanfidziyyah. Al-sulthah al-tanfidziyyah merupakan kekuasaan eksekutif yang meliputi persoalan imamah, bai'ah, wizarah, dan waliy al-ahdi. Menurut al-Maududi, lembaga eksekutif dalam Islam dinyatakan dengan istilah ulil amri dan dikepalai oleh seorang amir atau khalifah. Dalam ketata negaraan negara mayoritas Islam dan menganut sistem presidensial seperti Indonesia hanya menonjolkan kepala negara dan kepala pemerintahan sebagai puncak roda untuk menjalankan urusan pemerintahan dan kenegaraan dalam menjalankan peraturan perundang-undangan dan sekaligus membuat kebijakan apabila dianggap perlu untuk mendatangkan manfaat demi kemaslahatan umat. Berdasarkan al-Qur`an dan Sunnah, umat Islam diperintahkan untuk mentaati ulil amri atau pemimpin suatu negara dengan syarat bahwa lembaga eksekutif ini mentaati Allah dan Rasul-Nya serta menghindari dosa dan pelanggaran.

Tugas al-sulthah al-tanfidziyyah adalah melaksanakan undang-undang. Negara memiliki kewewenangan untuk menjabarkan dan mengaktualisasikan perundang-undangan yang telah dirumuskan tersebut. Dalam hal ini negara melakukan kebijaksanaan baik yang berhubungan dengan urusan dalam negeri maupun yang menyangkut dengan hubungan antar negara (hubungan internasional).

Hubungan fiqh siyasah dusturiyah dengn penerapan bantuan bedah rumah ini terletak pada tugas dari lembaga eksekutif (al-sulthah al-tanfidziyyah) yangmana lembaga eksekutif (alsulthah al-tanfidziyyah) bertugas melasanakan Undang-undang dan peraturan-peraturan yang telah di tetapkan, dalam hal ini peraturan yang harus di laksanakan adalah peraturan Menteri PUPR No 13/PRT/M/2016 tentang bantuan stimulan perumahan swadaya di dalam islam kita di wajibkan untuk mematuhi apa yang di tetapkan oleh para pemimpin apabila tidak bertentangan dengan syariat Islam begitupun dengan mematuhi peraturan yang telah di 
bentuknya selagi tidak melenceng dari ajaran islam sebagaimana yang tercantum dalam firman Allah SWT dalam QS AL-Nisa 58-59:

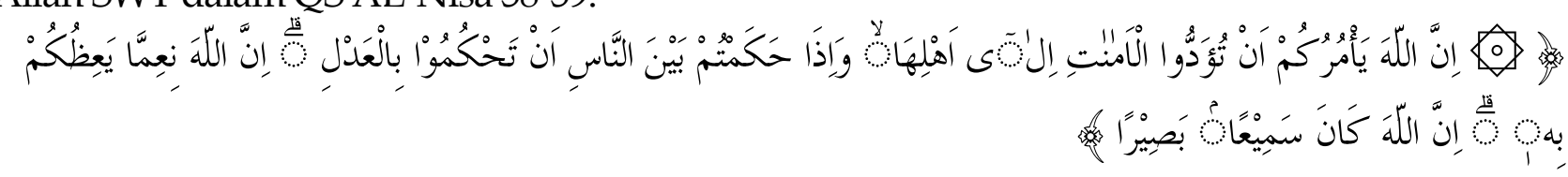

Artinya: Sesungguhnya Allah menyuruh kamu menyampaikan amanat kepada yang berhak menerimanya, dan (menyuruh kamu) apabila menetapkan hukum di antara manusia supaya kamu menetapkan dengan adil. Sesungguhnya Allah memberi pengajaran yang sebaikbaiknya kepadamu. Sesungguhnya Allah adalah Maha mendengar lagi Maha Melihat.

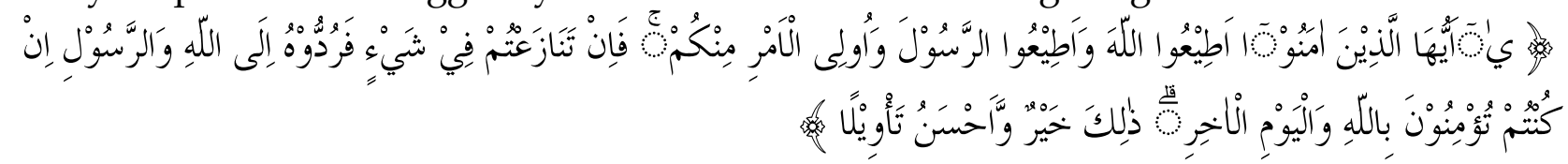

Artinya: Hai orang-orang yang beriman, taatilah Allah dan taatilah Rasul (nya), dan ulil amri di antara kamu. Kemudian jika kamu berlainan pendapat tentang sesuatu, Maka kembalikanlah ia kepada Allah (Al Quran) dan Rasul (sunnahnya), jika kamu benar-benar beriman kepada Allah dan hari kemudian. yang demikian itu lebih utama (bagimu) dan lebih baik akibatnya.

Dari ayat tersebut di jelaskan bahwa sebagai seorang pemimpin hendaknya menyampaikan amanat kepada yang berhak menerimanya dan menetapkan hukum dengan adil kepada seluruh masyarakat tampa memandang status dan derajatnya. Selain seorang pemimpin di wajibkan menetapkan hukum dengan adil, kita sebagai orang muslim juga di wajibkan untuk taat kepada ulil amri (pemimpin) termasuk mentaati apapun yang telah di tetapkan oleh pemimpin baik undang- undang maupun peraturan apabila tidak bertentangan dengan syariat islam.

Keterkaitan permasalah dengan Fiqh Siyasah Dusturiyah adalah dimana seorang pemimpin dalam islam di wajibkan untuk menyampaikan amanah kepada yang berhak menerimanya dan menetapkan hukum dengan adil kepada seluruh masyarakat.

Dalam prinsip fiqh siyasah hal ini termasuk kedalam Prinsip keadilan dan Prinsip hak,kewajiban negara dan rakyat Prinsip keadilan adalah kunci utama penyelenggaraan negara. Keadilan dalam hukum menghendaki setiap warga negara sama kedudukannya didepan hukum tampa memandang status derjat maupun rasnya sehingga tercapailah masyarakat yang aman dan damai karena tidak adanya cemburu sosial akibat dari ketidak adilan di dalam masyarakat.

Prinsip Hak dan kewajiban negara dan rakyat “ berdasarkan QS Al-Nisa 59. Semua warga negara di jamin hak-hak dasartertentu. Menurut Subhi Mahhmasani dalam bukunya Arkan huquh al-insan menjelaskan beberapa hak warga negara yang perlu di lindungi adalah : Jaminan terhadap kemanan pribadi, harga diri dan harta benda, kemerdekaan untuk mengeluarkan pendapat dan berkumpul, hak untuk mendapatkan pelayanan hukum dengan adil tampa diskriminasi, hak,kewajiban negara dan rakyat. Tindakan imam terhadap rakyatnya harus di kaitkandengan kemaslahatan dimana tindakan seorang pemimpin atau penguasa harus sejalan dengan kepentingan umum bukan untuk golongan atau dirisendiri, pemimpin merupakan sebuah keniscayaan dalam sebuah perkumpulan ataupun suatu badan. karena tampa seorang pemimpin maka suatuperkumpulan tidak akan berjalan dengan baik. salah satu bentuk kekuasaan pemimpin adalah memutuskan suatu perkara atau menentukan suatu 
kebijakan, maka jia berpegangan kepada kaidah di atas apa yang di putuskan oleh seorang pemimpin atau kebijakan yang di ambil harus memiliki orientasi yang baik yang membawa kemaslahatan kepada yang dipimpinnya. (Usman, 2002: 144)

\section{KESIMPULAN}

Berdasarkan hasil penelitian dan analisis data, dapat ditarik kesimpulan sebagai berikut; Bahwa penyebab mekanisme penetapan bantuan stimulan perumahan swadaya di Jorong Buluh Kasok tidak tepat sasaran adalah adanya pihak yang tidak melaksanakan tugasnya secara teknis yang telah di tentukan. Dari ke tiga penanggung jawab dan peksana bantuan bedah rumah pihak yang tidak melaksanakan tugasnya secara keseluruhan adalah Tim Teknis bedah rumah yangmana tugas tim teknis bedah rumah merupakan melakukan pengawasan terhadap pelaksanaan bantuan bedah rumah sebagaimana yang tertera dalam Peraturan Menteri No 13/PRT/M/2016 Tim teknis bantuan bedah rumah bertugas melakukan pengawasan dan pengendalian serta melakukan pemantauan dan evaluasi terhadap pemberian bantuan bedah rumah.

Berdasarkan pandangan Fiqh Siyasah Dusturiyah terhadap prosedur penetapan bantuan stimulan perumahan swadaya ini terletak pada tugas dari lembaga eksekutif (al-sultah altanfidziyah) yang mana tugas dari lembaga al- sultah al-tanfidziyah adalah melaksanakan undang-undang dan peraturan yang telah di tetapkan, dalam prinsip fiqh siyasah hal ini termasuk kedalam prinsip keadilan dimana untuk menciptakan keadilan tidak boleh memandang status maupun jabatan karena semuanya sama kita sama allah.

\section{DAFTAR PUSTAKA}

Az-Zuhaili, W. (2016). Tafsir al-Munir. Jakarta: Gema Insani

Iqbal, M. (2016). Fiqh Siyasah Kontekstual Doktrin Politik Islam. Jakarta: Perpustakaan Nasional

Quthb, S. (2001). Tafsir fi Zhilalil Qur'an. Jakarta: Gema Insani

Sugiyono. (2013). Metode penelitian kualitatif Dan RED. Bandung: Alfabeta

Peraturan Presiden Republik Indonesia Nomor 15 Tahun 2015

Peraturan Menteri PUPR No 13/PRT/M/2016 Tentang Bantuan Stimulasi Perumahan Swadaya

Undang-Undang Dasar Negara Republik Indonesia pasal 1 ayat 3 Tahun 1945

Undang-Undang Republik Indonesia Tahun 2011 Tentang Perumahan dan Kawasan Pemukiman 